members are put down as thirty-seven per cent there is really not much in it. In regard to reaction to school conditions this is said to have been 'good' in eighty-one per cent and in nineteen per cent 'bad', whereas it might well have been expected to be the other way round.

A further point of interest which comes out of these statistics of the N.S.W. Stammerers' Club is that seventy-six per cent stammerers were boys and twenty-four per cent girls; moreover, the serious influence of this disability in the case of the latter as regards life as a whole is suggested by the figures which tell us that at thirty years of age approximately seventy-three per cent of the boys had got married whilst only thirty-seven per cent of the girls had been equally successful.

Usually relief of stammering depends on the determination of the individual sufferer who will make use of certain rules of elocution and self-help such as are readily accessible from teachers and handbooks on the subject. Certainly the stammerer who sets out to cure his difficulty must attain three objects ; namely, (1) confidence ; (2) attainment of a new habit; (3) the maintenance of a restful state of mind and body. He must learn to relax. He must learn to use a new voice with a timing slightly but definitely different from that which he habitually uses when stammering. He can look forward confidently, if he determines to practice and to rely on himself; in any case he can perhaps take some comfort from remembering that he is one of a com. pany of very famous men. Amongst kings one may remember that Louis II and Louis XIII of France are said to have stammered badly. Whilst at least one Queen of England (Mary II) was also troubled in the same way. I have always understood that Charles Lamb abandoned an intended career in the Church because of his speech disability, although stammering has not always been incompatible with a reputation as a famous speaker. Charles Kingsley, Phillips Brooks and Father Hugh Benson, all distinguished in the pulpit, are said to have stammered at times.

\section{E. L. HOPEWELL-ASH}

\title{
South-Eastern Union of Scientific Societies
}

\author{
Annual Congress at Hastings
}

\begin{abstract}
$\mathrm{T}$ HE forty-second Congress of the South-Eastern Union of Scientific Societies was held at Hastings on June 8-12. The Mayor of Hastings, Alderman A. Blackman, welcomed a large gathering of representatives of affiliated societies and other members of the Union at the opening ceremony on June 8, when Prof. F. E. Weiss was installed as president of the Union for the ensuing year, and delivered his presidential address on "Competition and Co-operation in Nature".

In the past, competition in commerce and industry was regarded as beneficial to the community, but competition among industrialists is no longer in such great favour, and oven in agriculture efforts are being made to restrict it. On the other hand, co-operation, which is the basis of communal organization, is not generally called in question. Prof. Weiss pointed out that these forces also exist in Nature. Darwin had pointed out that, owing to the enormous reproductive capacity of most plants and animals, a weeding out process is inevitable; there is a struggle for existence under which only the fit survive. Many plants produce hundreds of thousands of seeds, but do not appreciably increase in numbers on an area already covered with vegetation. In the case of plants, the struggle for light is often the dominant factor. There is also competition for the necessary food among animals, and the larger and stronger animals have an advantage over the smaller and weaker ones. In the case of carnivorous animals, however, the race is not always to the strong, but also largely to the swift and agile. Though the dictum "Nature red in tooth and claw" causes some people to regard evolution as a continuous competitive warfare in which might is always triumphant, Darwin pointed out that there are certain instinctive characters in many animals which make for the preservation of the race as a
\end{abstract}

whole and as apart from the individuals, and that probably in these the basis of our moral nature had its beginnings. Parental instincts play a very important part in the survival of the more highly developed animals; there is here no competition for food between parents and offspring, but, on the contrary, parents will often starve themselves for the benefit of their young. Prof. Weiss then dealt with numerous cases of symbiosis, the classical example in plants being found in lichens. He took two ex amples to illustrate competition and co-operation among plants, the rosette-forming plants of grass lands illustrating competition, and plants of the Leguminoseæ with their nodules carrying nitrifying bacteria exemplifying co-operation.

"Our Changing Flora" was the theme of an address delivered by Dr. R. W. Butcher to the Botanical Section of the Union. Man has brought about remarkable changes in the flora of Great Britain. The draining of fens, the turning of heathland into forest, rivulets made into canals, the digging of railway cuttings and making embankments have all played an important part in bringing about changes. There never has been, and probably never will be, anything static about the flora. The ecologist recognizes a continual change of vegetation as a basic principle in plant succession. Captain Diver has directed attention to rapid topographical changes in the South Haven peninsula of Dorset since 1700 . Large masses of lsoetes echinospora are now found on the bed of Littlesea, yet this plant was unknown there a few years ago. Pearsall has recorded many changes in the vegetation of the English Lakes, these changes being in accord with changes in the nature of the lake bottoms.

Mr. L. F. Salzman gave a paper on "The Writing of Local History" to members of the Archæological 
Section. He likened a local history to a large-scale map, for, he said, it is possible to indicate on such a map features which cannot be shown on a map portraying a whole country. In a local history it is thus possible to emphasize the human side of history.

To the same section Alderman T. S. Dymond read a paper on "The Cinque Ports Barons returned to Parliament, 1366 to 1722 ". Though the "Return of Members of Parliament", ordered by the House of Commons to be printed in 1878, began with the year 1290, the names of representatives from the Cinque Ports date from 1366 only. From that year until 1844, two members sat for Hastings. Before Queen Elizabeth's time, a representative from the free barons of the Port was chosen. Down to the great Reform Bill, freemen, elected by the bailiff (mayor) and jurats, alone had the franchise; by 1831 their number had fallen to twenty-three. At the election following the Reform Bill, Mr. North (father of Miss North, famous for the collection of Nature paintings in the North Gallery in Kew Gardens) was elected by 356 votes. In contrast with this number, 20,955 votes were cast for the successful candidate at the last election.

"Fossils in their Original Environment" was the subject of a lecture given by Dr. H. Dighton Thomas to the Geological Section. Dealing first with Trilobites, Dr. Dighton Thomas said that the loss of eyes in these organisms was co-related with their burrowing habits ; the Welsh beds were deposited in deep water, and in them the Trilobites show a reduction in the development of eyes, and one of them was blind. Brachiopods were common in shallow water after the Devonian period. Changes in the fauna of deposits were brought about by changing conditions of salinity in the water. He does not regard chalk as a foraminiferal limestone, but as a Foraminifera-bearing limestone. The bulk of the chalk is of shallow water origin, and its fauna is not a deep water one. $\mathrm{He}$ suggested the collection of fossils from differing horizons in the chalk and the determination of the fauna of the separate zones, as there is a lack of knowledge of the succession of the fauna in chalk in England. The flora and fauna of the London Clay are those of a tropical sea, and plants similar to those in it are still found in lowland tropical countries, Nipa swamps being cited.

Many interesting excursions to places of interest around Hastings were made. At Ashburnham Place, Lady Catherine Ashburnham kindly allowed the King Charles I relics to be inspected, and on the same excursion the sites of Sussex ironworks were visited. The smelting of iron ore and the forging of wrought iron on these sites date from very early times, and were carried on at the site visited until about 1813 , the last of the ironworkers dying in a cottage close by in 1883. The geologists paid a visit to Crowhurst Quarry, where faulting is very clearly seen, and one of the visitors picked up a scale, apparently from a turtle, with the markings on the back clearly defined. The natural gas bore at Heathfield Station was inspected. Visits were also paid to local churches and to Pett Level, where, owing to exceptionally low tide, the remains of the submerged forest were plainly visible.

At the annual representative assembly, it was announced that the 1938 Congress would be held at Worthing, under the presidency of Dr. Julian Huxley. Mr. A. W. Farquharson, of Le Play House, 33 Gordon Square, London, was elected honorary general secretary.

\section{Science News a Century Ago}

\section{A Spanish Manuscript on Tahiti}

Among the donations presented to the Royal Geographical Society at its meeting on June 26, 1837, was a Spanish manuscript, being the "Diary of an Expedition to, and Residence upon the Island of Tahiti", by Maximo Rodriguez, written in 1774 . Rodriguez had accompanied an expedition from Lima to Tahiti, and with three other persons had spent about thirteen months in the island. Cook had heard of the visit of the Spaniards and had written: "Will anything ever become known to the world of the proceedings of the Spaniards at this island ?" After a lapse of sixty years the diary was placed in the hands of a captain in the Royal Navy and by him presented to the daughter of Rodriguez, who having heard that Captain FitzRoy was making inquiries for manuscripts sent it to him begging his acceptance of it, saying that "she felt sure it would be better placed in the hands of an Englishman, and more valued in England, than it ever could be, concealed from the world, and uncared for, in her library at Lima".

\section{The Institution of Civil Engineers}

IN a memorandum issued on July 1, 1837, from 1 Cannon Row, Westminster, the Council of the Institution of Civil Engineers directed attention to the following subjects for communications and for premiums, during the session of 1838 : the nature and properties of steam; the warming and ventilation of public buildings; accounts and drawings of the Plymouth Breakwater; the rates, from actual experiments, of the velocity, load and power of locomotive engines on railways, first upon levels, second upon inclined planes; description and account of the principles of Huddart's rope-making machinery at Limehouse ; the sewerage of Westminster, and drawings and accounts of the shield used at the Thames Tunnel.

\section{A Peat-Compressing Press}

The Mechanics' Magazine of July 1, 1837, contained a description of an improved machine for compressing peat invented by the Right Hon. Lord Willoughby d'Eresby. The machine was an upright press at the bottom of which was a rectangular cast-iron box into which a rectangular piston could be forced downwards by means of a rack and pinion. The interior of the box was lined with vertical iron bars between which small spaces were left so that the water could escape as the peat was compressed. "I find", wrote the inventor, "that the machine answers perfectly on about half the sorts of peat usually consumed, that is to say, on those of a fibrous quality; and I am still carrying on the experiment on a large scale. The peat when compressed, has been used with perfect success, instead of coal, for the purpose of calcining lime, for the smith's forge as well as for ordinary fuel."

\section{The Museums of Copenhagen}

ON July 2, 1837, Lyell wrote from Copenhagen to one of his sisters: "In the time of Linnæus this city contained finer collections of shells, and finer works were published here by Chemnitz (12 vols.) and 